\title{
The Intermediate Temperature Electrochemical Properties of Silver and Aluminum Double-Doped Strontium Silicate
}

\author{
Chang Wang, Ruifeng Du, Yan Han, Hongtao Wang* \\ School of Chemical and Material Engineering, Fuyang Normal University; Anhui Provincial Key \\ Laboratory for Degradation and Monitoring of Pollution of the Environment, Fuyang 236037, China \\ *E-mail: hwang@fync.edu.cn
}

doi: $10.20964 / 2019.07 .41$

Received: 4 March 2019/ Accepted: 5 May 2019 / Published: 10 June 2019

In this study, $\mathrm{Sr}_{0.6} \mathrm{Ag}_{0.4} \mathrm{SiO}_{3-\alpha}$ and $\mathrm{Sr}_{0.6} \mathrm{Ag}_{0.4} \mathrm{Si}_{0.9} \mathrm{Al}_{0.1} \mathrm{O}_{3-\alpha}$ electrolytes were synthesized via a high temperature solid state reaction method using $\mathrm{SrCO}_{3}, \mathrm{SiO}_{2}, \mathrm{AgNO}_{3}$ and $\mathrm{Al}_{2} \mathrm{O}_{3}$ as raw materials. The phase purities and morphologies of $\mathrm{Sr}_{0.6} \mathrm{Ag}_{0.4} \mathrm{SiO}_{3-\alpha}$ and $\mathrm{Sr}_{0.6} \mathrm{Ag}_{0.4} \mathrm{Si}_{0.9} \mathrm{Al}_{0.1} \mathrm{O}_{3-\alpha}$ were confirmed by Xray diffractometer and scanning electron microscopy. SEM photos showed that $\mathrm{Sr}_{0.6} \mathrm{Ag}_{0.4} \mathrm{SiO}_{3-\alpha}$ and $\mathrm{Sr}_{0.6} \mathrm{Ag}_{0.4} \mathrm{Si}_{0.9} \mathrm{Al}_{0.1} \mathrm{O}_{3-\alpha}$ pellets were well-sintered. The Arrhenius plots indicated that the activation energies of $\mathrm{Sr}_{0.6} \mathrm{Ag}_{0.4} \mathrm{SiO}_{3-\alpha}$ and $\mathrm{Sr}_{0.6} \mathrm{Ag}_{0.4} \mathrm{Si}_{0.9} \mathrm{Al}_{0.1} \mathrm{O}_{3-\alpha}$ are $107.3 \pm 3.2 \mathrm{~kJ} \cdot \mathrm{mol}^{-1}$ and $107.7 \pm 2.1$ $\mathrm{kJ} \cdot \mathrm{mol}^{-1}$ in nitrogen atmosphere from $400{ }^{\circ} \mathrm{C}$ to $800{ }^{\circ} \mathrm{C}$, respectively. $\mathrm{Sr}_{0.6} \mathrm{Ag}_{0.4} \mathrm{SiO}_{3-\alpha}$ showed the highest maximum power density of $48.5 \mathrm{~mW} \cdot \mathrm{cm}^{-2}$ at $800{ }^{\circ} \mathrm{C}$.

Keywords: Electrolyte; Fuel cell; Conductivity; Strontium silicate

\section{$\underline{\text { FULL TEXT }}$}

(C) 2019 The Authors. Published by ESG (www.electrochemsci.org). This article is an open access article distributed under the terms and conditions of the Creative Commons Attribution license (http://creativecommons.org/licenses/by/4.0/). 